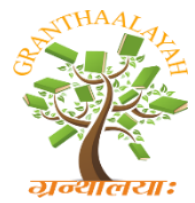

\author{
INTERNATIONAL JOURNAL OF RESEARCH - \\ GRANTHAALAYAH \\ A knowledge Repository
}

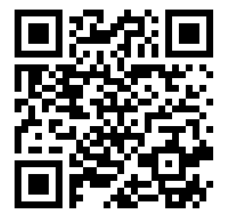

Science

\title{
SMALLHOLDER FARMERS' ATTITUDE TOWARD QUALITY SEED OF IMPROVED COMMON BEAN VARIETIES IN TANZANIA
}

\author{
Joshua S. Kidudu *1, Dismas L. Mwaseba ${ }^{2}$, Susan Nchimbi-Msolla ${ }^{3}$ \\ *1,2 Department of Agricultural Extension and Community Development, College of Agriculture, \\ Sokoine University of Agriculture, P.O Box 3002, Morogoro, Tanzania \\ ${ }^{3}$ Department of Crop Science and Horticulture, College of Agriculture, Sokoine University of \\ Agriculture, P.O Box 3005, Morogoro, Tanzania
}

\begin{abstract}
The importance of quality seed of improved varieties is well recognized and widely documented. However, smallholder farmers' demand for quality seed of improved varieties has remained low for years. Previous studies have broadly identified technological, economic, institutional and human specific factors as major determinants of adoption. However, these studies tended to pay little attention on the influence of smallholder farmers' attitude on decision to use quality seed of improved common bean varieties. Therefore, using cross-sectional research design, a survey was conducted in major regions producing common beans to determine smallholder farmers' attitude towards quality seed of improved common bean varieties. Generally, smallholder farmers considered quality seed of improved common bean varieties to be beneficial (2.0616). However, they had moderate positive attitude towards qualities (1.4705) and accessibility (1.4598) of quality seed of improved common bean varieties. Nevertheless, they had very weak positive attitude toward availability (0.3068), promotion (0.3432) and marketability (0.3326) of their produce. Furthermore, findings indicated that benefits, qualities and marketability significantly influenced their attitude. These findings suggest that efforts to promote quality seed use have to concentrate on ensuring quality of claimed to be quality seeds and market outlets for produce from quality seed of improved common bean varieties.
\end{abstract}

Keywords: Quality Seed; Attitude; Accessibility; Promotion; Marketability; Availability.

Cite This Article: Joshua S. Kidudu, Dismas L. Mwaseba, and Susan Nchimbi-Msolla. (2019). "SMALLHOLDER FARMERS' ATTITUDE TOWARD QUALITY SEED OF IMPROVED COMMON BEAN VARIETIES IN TANZANIA." International Journal of Research - Granthaalayah, 7(5), 71-80. https://doi.org/10.29121/granthaalayah.v7.i5.2019.826.

\section{Introduction}

Common bean is an important crop in areas producing this crop. It is the second most important crop after maize in villages producing common beans. However, productivity has remained low to many smallholder farmers producing common beans for years. The reason behind low productivity 
among others is predominant use of grains as seed in production. Using quality seed of improved common bean varieties stands a chance to increase productivity.

Studies on the contribution of quality seed of improved varieties to increased productivity are well documented. For example, [1] indicates that when quality seed of improved variety is used in production yield increases by 10 to $15 \%$. In a similar vein, [2] cited by [3] reported an increase in yield by $30 \%$ to $50 \%$ when quality seed of improved common bean variety was used in production. Furthermore, [4] reported an increase by $22 \%$ when improved common bean varieties are used in production.

Nevertheless, smallholder farmers' demand for quality seed of improved varieties has remained low for years. Seed studies have indicated that only 5\% [5]; 3-20\% [6]; <20\% [7]; 10\% [8] 4\% [9; $10]$ of farmers use quality seed of improved varieties. This has led to low crop productivity which in turn may lead to food and nutrition insecurity as well as low family income.

Despite smallholder farmers' low use of quality seed of improved common bean varieties, information as to why there is low use is scanty. This study adds to the existing literature by investigating smallholder farmers' attitude towards quality seed of improved common bean varieties. Attitude refers to a tendency revealed through varying degrees of favourable or unfavourable judgments [11]. Determining whether smallholder farmers have favourable or unfavourale attitude towards quality seed of improved common bean varieties is necessary before farmers are accused of not using quality seeds. For instance, [12] found the level of adoption as well as positive attitude to be higher among the sustained users than abandoned users.

When addressing attitude, [13] used the words favorable or unfavorable, desirable or undesirable, good or bad, likes or dislikes, pleasing or displeasing, and behavioral readiness associated with it. As we address smallholder farmers' attitude toward quality seed of improved common bean varieties, we need to establish whether farmers consider them to be favorable or unfavorable, desirable or undesirable, good or bad, pleasing or displeasing, and their behavioral readiness associated with using them.

However, common variables considered in adoption models as factors influencing adoption decisions include extension, education, age, family size/labor, credit and income ignoring attitude possessed by adopters towards a given technology [14]. Therefore, this study adds to the existing body of knowledge by determining smallholder farmers' attitude toward quality seed of improved common bean varieties.

\section{Materials and Methods}

Using cross-sectional research design, a survey of smallholder farmers in four regions was conducted. To obtain representative smallholder farmers who participated in a survey, a multistage sampling technique was used. In the first stage main regions producing common beans were randomly selected from major common beans producing zones. The main zones included Eastern, Lake/western, Northern, and, southern highlands. For the eastern zone main common beans producing regions included Morogoro and Tanga. In the lake/western zone main common beans producing regions included Geita, Kagera, and Kigoma. For the northern zone main common 
beans producing regions included Arusha, Kilimanjaro and Manyara. The southern zone comprised of Iringa, Katavi, Mbeya, Njombe, Rukwa, Ruvuma, and Songwe.

In the first stage therefore Kigoma, Manyara, Mbeya and Morogoro regions were randomly selected to represent major common beans producing zones. In the second stage one representative district was randomly selected from each representative region. At this stage Babati, Kasulu, Mbeya and Mvomero districts were selected. In the third stage study villages were randomly selected from representative districts. The fourth stage came up with 320 smallholder farmers randomly selected to represent other farmers producing common beans in Tanzania. Nevertheless, 311 smallholder farmers participated in the study. Nine farmers had other responsibilities during data collection.

To gain entry to the study sites and access to participants, permits were obtained from Sokoine University of Agriculture and local government authorities. Working with local government officials and agricultural extension workers, informed consent was obtained from participants before data collection. During the survey a questionnaire was used to collect data in Dudiye, Endanoga, Gallapo and Tsaayo villages from Babati District. From Kasulu District the questionnaire was used in Heru Juu, Kanazi, Kigondo and Ruhita villages. For Mbeya District the questionnaire was used in Idiga, Itimu, Iwindi, Mshewe and Songwe Viwandani villages. For Mvomero District the questionnaire was used in Ndole and Magunga villages.

Adding to a questionnaire, focus group discussions were conducted in Belmi, Orngadadi, Tsamani, and Seloto villages from Babati District. From Kasulu District focus group discussions were conducted in Murufiti, Mganza, Nyumbigwa and Ruhita villages. Villages from Mbeya were Mapogolo and Itimba.

To measure smallholder farmers' attitude toward quality seed of improved common bean varieties, content and thematic analysis was used to determine emerging themes. The themes included quality seed availability, benefits, accessibility, qualities, promotion and marketability. Positive and negative statements were generated and used to measure smallholder farmers' attitude on quality seed of improved common bean varieties. The statements were arranged on a seven point Likert scale which ranged from Strongly agree $=3$, Moderately agree $=2$, Slightly agree $=1$, Neutral $=0$, Slightly disagree $=-1$, Moderately disagree $=-2$ to Strongly disagree $=-3$. Based on theme's attributes average score was computed. Furthermore, the influence of each attribute on smallholder farmers' attitude to use quality seed of improved common bean varieties was determined using linear regression analysis.

\section{Results and Discussions}

Main themes influencing smallholder farmers' attitude toward quality seed of improved common bean varieties included seed availability, benefits of quality seeds, accessibility of quality seeds, qualities of quality seeds, promotion of quality seeds and marketability of common bean produces from improved varieties. Mean values for each theme was computed and the findings are presented in Table 1. 
Table 1: Mean score per theme influencing smallholder farmers attitude towards quality seed of improved common bean varieties

\begin{tabular}{|l|l|l|l|l|l|}
\hline Theme & $\mathbf{N}$ & Minimum & Maximum & Mean & Std. Deviation \\
\hline Benefits of quality seed & 311 & -2.00 & 3.00 & 2.0616 & .91041 \\
\hline Qualities of quality seed & 311 & -3.00 & 3.00 & 1.4705 & .97405 \\
\hline Accessibility of quality seed & 311 & -3.00 & 3.00 & 1.4598 & 1.49158 \\
\hline Promotion of Quality seed & 311 & -2.88 & 3.00 & .3432 & 1.27734 \\
\hline Marketability of Quality seed produce & 311 & -3.00 & 3.00 & .3326 & 1.50274 \\
\hline Quality seed availability & 311 & -3.00 & 3.00 & .3068 & 1.50934 \\
\hline Overall attitude & $\mathbf{3 1 1}$ & $\mathbf{- 2 . 0 0}$ & $\mathbf{3 . 0 0}$ & $\mathbf{. 9 9 5 7}$ & $\mathbf{. 7 8 7 6 9}$ \\
\hline
\end{tabular}

The findings in Table 1 indicate that, generally, smallholder farmers consider quality seed of improved common bean varieties to be beneficial as they have moderate to strong positive attitude (2.0616). However, they have neutral to very weak positive attitude toward availability (0.3068) as well as marketability (0.3326) of their produce and promotion (0.3432). Furthermore, smallholder farmers have weak to moderate positive attitude towards qualities (1.4705) and accessibility to quality seed of improved common bean varieties (1.4598). Having weak positive attitude towards quality seed of improved common bean varieties brings the need to improve smallholder farmers' attitude.

The extent to which each of the theme influences smallholder farmers' attitude is presented in Table 2. The findings indicate that although all themes have influence on smallholder farmers' attitude towards quality seed of improved common bean varieties, benefits of quality seed, seed quality attributes and marketability of common bean produces from quality seed have a significant influence on smallholder farmers attitude towards quality seed of improved common bean varieties.

Table 2: The influence of various themes on smallholder farmers' attitude towards quality seed of improved common bean varieties

\begin{tabular}{|c|c|c|c|c|c|}
\hline \multirow[t]{2}{*}{ Theme influencing attitude } & \multicolumn{2}{|c|}{$\begin{array}{l}\text { Unstandardized } \\
\text { Coefficients }\end{array}$} & \multirow{2}{*}{$\begin{array}{c}\text { Standardized } \\
\text { Coefficients }\end{array}$} & \multirow[t]{2}{*}{$\mathbf{t}$} & \multirow[t]{2}{*}{ Sig. } \\
\hline & B & Std. Error & & & \\
\hline Constant & 4.785 & .108 & & 44.313 & $.000 * *$ \\
\hline Benefits of quality seed & .291 & .052 & .333 & 5.560 & $.000 * *$ \\
\hline Qualities of quality seed & .118 & .050 & .144 & 2.365 & $.019 *$ \\
\hline $\begin{array}{l}\text { Marketability of Quality seed } \\
\text { produce }\end{array}$ & -.069 & .030 & -.131 & -2.308 & $.022 *$ \\
\hline Accessibility of quality seed & .044 & .030 & .083 & 1.458 & .146 \\
\hline Quality seed availability & -.036 & .030 & -.068 & -1.206 & .229 \\
\hline Promotion of Quality seed & .002 & .035 & .003 & .059 & .953 \\
\hline
\end{tabular}


The findings in Table 3 indicate that although all benefits related attributes have influence on smallholder farmers' attitude towards quality seed of improved common bean varieties, profit and seed quality assurance have significant influence on smallholder farmers attitude.

Table 3: The influence of benefits attributes on smallholder farmers' attitude towards quality seed of improved common bean varieties

\begin{tabular}{|c|c|c|c|c|c|}
\hline \multirow[t]{2}{*}{ Benefits attribute } & \multicolumn{2}{|c|}{$\begin{array}{l}\text { Unstandardized } \\
\text { Coefficients }\end{array}$} & \multirow{2}{*}{$\begin{array}{c}\begin{array}{c}\text { Standardized } \\
\text { Coefficients }\end{array} \\
\text { Beta }\end{array}$} & \multirow[t]{2}{*}{$\mathbf{t}$} & \multirow[t]{2}{*}{ Sig. } \\
\hline & $\mathbf{B}$ & Std. Error & & & \\
\hline Constant & 6.146 & .098 & & 62.483 & $.000 * *$ \\
\hline $\begin{array}{l}\text { Using quality seed of improved common bean } \\
\text { varieties assures one quality strongly agree }\end{array}$ & -.136 & .045 & -.206 & -3.028 & $.003 * *$ \\
\hline $\begin{array}{l}\text { When you use quality seed of improved } \\
\text { common varieties in production you get high } \\
\text { profit hence improved livelihood strongly } \\
\text { agree }\end{array}$ & -.073 & .037 & -.115 & -1.974 & $.049 *$ \\
\hline $\begin{array}{l}\text { Using quality seed of improved common bean } \\
\text { varieties improves farmer's income strongly } \\
\text { agree }\end{array}$ & -.071 & .038 & -.118 & -1.872 & .062 \\
\hline $\begin{array}{l}\text { Using quality seed of improved common bean } \\
\text { varieties will improve my expertise in common } \\
\text { bean production strongly agree }\end{array}$ & -.061 & .036 & -.107 & -1.687 & .093 \\
\hline $\begin{array}{l}\text { Using quality seed of improved common bean } \\
\text { varieties assures ones' body nutritionale } \\
\text { requirement agree }\end{array}$ & -.023 & .024 & -.054 & -.973 & .331 \\
\hline \begin{tabular}{|l|} 
Using quality seed of improved common bean \\
varieties loses local landraces agree
\end{tabular} & .013 & .017 & .040 & .782 & .435 \\
\hline $\begin{array}{l}\text { Using quality seed of improved common bean } \\
\text { varieties assures ones' seed security strongly } \\
\text { agree }\end{array}$ & -.026 & .035 & -.047 & -.737 & .461 \\
\hline
\end{tabular}

Paying attention on benefits of quality seed of improved common bean varieties, smallholder farmers in focus group discussion indicated that "When you use quality seed of improved common varieties in production you get high profit hence improved livelihood" they also informed that "Using quality seed of improved common bean varieties assures one quality".

The findings in Table 4 indicate that although all quality seed related attributes have influence on smallholder farmers' attitude towards quality seed of improved common bean varieties, high germination capacity, suitability to microclimate condition and quality seeds' high yielding ability have significant influence on smallholder farmers attitude towards quality seed of improved common bean varieties. 
Table 4: The influence of qualities of quality seed on smallholder farmers' attitude toward quality seed of improved common bean varieties

\begin{tabular}{|c|c|c|c|c|c|}
\hline \multirow[t]{2}{*}{ Quality Seed attribute } & \multicolumn{2}{|c|}{$\begin{array}{l}\text { Unstandardized } \\
\text { Coefficients }\end{array}$} & \multirow{2}{*}{$\begin{array}{c}\begin{array}{c}\text { Standardized } \\
\text { Coefficients }\end{array} \\
\text { Beta } \\
\end{array}$} & \multirow[t]{2}{*}{$\mathbf{t}$} & \multirow{2}{*}{ Sig. } \\
\hline & $\mathbf{B}$ & Std. Error & & & \\
\hline (Constant) & 5.949 & .126 & & 47.077 & $.000 * *$ \\
\hline $\begin{array}{l}\text { Common beans produced using quality seed of } \\
\text { improved common bean varieties have higher } \\
\text { yield strongly agree }\end{array}$ & -.145 & .047 & -.213 & -3.070 & $.002 * *$ \\
\hline $\begin{array}{l}\text { Quality seed of improved varieties are suitable at } \\
\text { our microclimate condition neutral }\end{array}$ & .046 & .018 & .136 & 2.521 & $.012 *$ \\
\hline $\begin{array}{l}\text { Quality seed of improved common bean varieties } \\
\text { have high germination capacity strongly agree }\end{array}$ & -.087 & .039 & -.144 & -2.244 & $.026 *$ \\
\hline $\begin{array}{l}\text { Weather variability influences use of quality seed } \\
\text { of improved common bean varieties agree }\end{array}$ & -.032 & .020 & -.090 & -1.644 & .101 \\
\hline $\begin{array}{l}\text { Common beans produced from quality seed of } \\
\text { improved common bean varietiesare tolerant to } \\
\text { diseases agree }\end{array}$ & -.029 & .021 & -.077 & -1.370 & .172 \\
\hline $\begin{array}{l}\text { Common beans sown with quality seed of } \\
\text { improved varieties are tolerant to drought } \\
\text { moderately agree }\end{array}$ & -.027 & .023 & -.069 & -1.172 & .242 \\
\hline $\begin{array}{l}\text { Quality seed of improved common bean varieties } \\
\text { mature early moderately agree }\end{array}$ & .016 & .025 & .039 & .653 & .515 \\
\hline $\begin{array}{l}\text { Prevalence of fake seed claimed to be quality } \\
\text { seed affects use of quality seed of improved } \\
\text { common bean varieties moderately agree }\end{array}$ & -.011 & .022 & -.028 & -.502 & .616 \\
\hline $\begin{array}{l}\text { Common beans produced using quality seed of } \\
\text { improved common bean varieties are uniform } \\
\text { moderately agree }\end{array}$ & .004 & .024 & .010 & .175 & .861 \\
\hline $\begin{array}{l}* * \text { Significant at the } 0.01 \text { level } \\
* \text { Significant at the } 0.05 \text { level }\end{array}$ & & & & & \\
\hline
\end{tabular}

Seed quality attributes are key in use of quality seed of improved common bean varieties. There are cases where farmers buy seed claimed to be quality seed but performance discourages users. Complaints about fake, adulterated or counterfeit seed are not new among farmers. [15] informed that there are problems of adulterated materials which undermine farmers' trust in agro-dealers and in use of agro-inputs. A similar situation was reported by [5]. In an attempt to establish trust relations among seed sector stakeholders, they found farmers to have perceived seed companies and agro dealers as providers of fake and too expensive seed.

This makes it difficult to use quality seed of improved varieties unless demonstrated in their field conditions before popularization. [16] reported prevalence of counterfeit seed in Tanzania. This puts farmers at risk of procuring unintended seed hence lose confidence with the claimed quality seed of improved varieties. This is the factor influencing use because farmers are worried of the quality. [9] investigated seed quality issue in South Western Nigeria and found that private 
individuals handling seed cannot afford the provision of conducive storage environment hence seed deteriorate faster in their hands.

The findings in Table 5 indicate that although all marketability related attributes have influence on smallholder farmers' attitude toward quality seed of improved common bean varieties, difficulties encountered in selling common bean produce from quality seed of improved varieties, the fact that most consumers do not prefer common beans produced from quality seed of improved common bean varieties, uniformity of produce from quality seed of improved varieties, and the fact that common bean produced from quality seed of improved common beans varieties are not tasty have significant influence on smallholder farmers attitude towards quality seed of improved common bean varieties.

Table 5: The influence of marketability of produce from quality seed of improved common bean varieties on smallholder farmers' attitude

\begin{tabular}{|c|c|c|c|c|c|}
\hline \multirow[t]{2}{*}{ Marketability attribute } & \multicolumn{2}{|c|}{$\begin{array}{l}\text { Unstandardized } \\
\text { Coefficients }\end{array}$} & \multirow{2}{*}{\begin{tabular}{|c|}
$\begin{array}{c}\text { Standardized } \\
\text { Coefficients }\end{array}$ \\
Beta
\end{tabular}} & \multirow[t]{2}{*}{$\mathbf{t}$} & \multirow[t]{2}{*}{ Sig. } \\
\hline & $\mathbf{B}$ & $\begin{array}{l}\text { Std. } \\
\text { Error }\end{array}$ & & & \\
\hline (Constant) & 5.581 & .126 & & 44.183 & $.000 * *$ \\
\hline $\begin{array}{l}\text { Many common buyers prefer local varieties } \\
\text { more than lmproved varieties agree }\end{array}$ & -.020 & .020 & -.063 & -.988 & .324 \\
\hline $\begin{array}{l}\text { It is difficult to sell produce from quality seed } \\
\text { of improved common beans in our village } \\
\text { neutral }\end{array}$ & .060 & .022 & .192 & 2.704 & $.007 * *$ \\
\hline $\begin{array}{l}\text { Market for selling produce from quality seed } \\
\text { of improved varieties is difficulty agree }\end{array}$ & -.026 & .022 & -.085 & -1.168 & .244 \\
\hline $\begin{array}{l}\text { Most consumers do not prefer common beans } \\
\text { produced from quality seed of improved } \\
\text { common bean varieties agree }\end{array}$ & -.059 & .022 & -.187 & -2.689 & $.008 * *$ \\
\hline $\begin{array}{l}\text { Lack of markets for selling common beans } \\
\text { produce from quality seed of improved } \\
\text { varieties agree }\end{array}$ & .026 & .021 & .087 & 1.277 & .203 \\
\hline $\begin{array}{l}\text { Common bean produced from quality seed of } \\
\text { improved common bean varieties are uniform } \\
\text { hence good for business strongly agree }\end{array}$ & -.096 & .026 & -.206 & -3.732 & $.000 * *$ \\
\hline $\begin{array}{l}\text { Common bean produced from quality seed of } \\
\text { improved common beans varieties are not } \\
\text { tasty neutral }\end{array}$ & .053 & .020 & .162 & 2.638 & $.009 * *$ \\
\hline \multicolumn{6}{|l|}{ **Significant at the 0.01 level } \\
\hline
\end{tabular}

Having low market potential implies difficulties to sell produce from improved common bean varieties. To a smallholder farmer assured market is a key because the produces have to be sold to be able to buy other necessities. Smallholder farmers' attitude toward quality seed of improved common bean varieties was also examined in focus group discussion. Citing examples of improved varieties, participants informed that "if you decide to grow improved varieties you will cry because 
you will never get customers, no one who is seeking to buy these varieties". Explaining about improved varieties which were once introduced and then disappeared in their village and district, participants highlighted that "some improved varieties shortly disappear after being introduced to smallholder farmers because they have no market".

From another focus group discussion participants indicated that if one wants to bring in new varieties then "Varieties brought must have place to sell them, you should not bring varieties which you fail to sell when a child is sick, wife will strongly blame you why did you bring these varieties which have no market". This implies that smallholder farmers' decision to use quality seed of improved common bean varieties will be promoted if the released varieties target consumers' preferences and hence assured smallholder farmers possibility to sell produce from these varieties. The same would eliminate what participants in another focus group discussion raised about what a farmer group experienced after producing improved varieties in a farmer field school. They informed that "the group doesn't sell because nobody seeks this variety, it is like a duck it is never sought".

The fact that new improved varieties face marketing challenges was also found by [17]. In their study they found continued use of new improved common bean varieties to be a challenge. Instead farmers continued to use old improved varieties because they acquired market outlet. In a situation where there is low market potential for the produce from improved common beans varieties, commercialization becomes difficult if not impossible. Basically the attitude possessed by respondents involved in the current study reflected what [18] found to be a principal constraint in common beans commercialization. In their study, market constraints were the key constraining common beans commercialization.

Agricultural experts continue to advice farmers to use quality seed of improved common bean varieties which lead to high yield but face the marketing challenge. A similar trend was found by [19] where consumption and postharvest attributes outweighed production traits. In focus group discussions it was indicated that when new varieties are introduced in the farming communities they shortly disappear because they lack market. This implies that for the variety to last long it must have a market outlet. This is a lesson to be considered by breeders before coming up with new varieties. There is need to establish consumer preferences before releasing new common bean varieties. This is what made [20] to recommend including traders and consumers as important actors in breeding. Involving common beans vendors, traders and consumers who play a significant role in distribution and marketing is very important for improved common beans to be used by smallholder farmers.

\section{Conclusions and Recommendations}

Smallholder farmers consider quality seed of improved common bean varieties to be beneficial. However, they have neutral to very weak positive attitude toward availability, promotion and marketability of their produce. Furthermore, they have weak to moderate positive attitude towards qualities and accessibility of quality seed of improved common bean varieties. Therefore, attempts to increase use of quality seed of improved common bean varieties have to strengthen availability, promotion and target marketable varieties. Moreover, assuring smallholder farmers on the quality 
of claimed to be quality seed as well as addressing accessibility stand better chances of increasing quality seed use.

Generally, smallholder farmers' attitude towards quality seed of improved common bean varieties is significantly influenced by benefits accrued from quality seed of improved common bean varieties $(p=0.000)$. Adding to quality seeds' benefits, smallholder farmers' attitude is also influenced by qualities of quality seeds $(\mathrm{p}=0.019)$. Furthermore, marketability of produce from quality seed of improved common bean varieties $(p=0.022)$ has a significant influence on smallholder farmers' attitude towards quality seed of improved common bean varieties.

These findings suggest that efforts to promote use of quality seed of improved common bean varieties have to concentrate on ensuring quality of claimed to be quality seeds as well market outlets for produce from quality seed of improved common bean varieties.

This calls for effective and efficient seed certification system as well as monitoring seed distribution and marketing. Therefore, TOSCI has to strengthen seed certification and inspection to ensure seed quality. It also calls for breeders to focus on improving market led varieties.

\section{Acknowledgement}

Acknowledgement is made to Sokoine University of Agriculture for permission to embark on this study. The university is further acknowledged for facilitating entry to study areas by issuing introductory letters to local governments for permits. Kirkhouse Trust is acknowledged for funding this study from inception to completion. PhD Supervisors are acknowledged for their continued guidance. Acknowledgement is made to local government authorities for permits to conduct research, Extension workers for coordinating fieldwork and Smallholder farmers for their willingness to actively participate in this study in all phases.

\section{References}

[1] Oyekale, K. O. Growing an Effective Seed Management System: A Case Study of Nigeria. Journal of Agriculture and Environmental Sciences 3(2), 2014, 345-354.

[2] Kalyebara, R., and Andima, D. The impact of improved bean technologies in Africa. Evaluation report submitted to the PABRA Steering Committee, Lumbumbashi, Democratic Republic of Congo, 27-29 March 2006.

[3] Rubyogo, J.C., Sperling, L., Muthoni, R. \& Buruchara, R. Bean Seed Delivery for Small Farmers in Sub-Saharan Africa: The Power of Partnerships. An International Journal of Society \& Natural Resources 23(4), 2010, 285-302.

[4] Birachi E. A., Ochieng J., Wozemba D., Ruraduma C., Niyuhire M.C. and Ochieng D. Factors Influencing Smallholder Farmers' Bean Production and Supply to Market in Burundi. African Crop Science Journal, 19 (4), 2011, 335 - 342.

[5] ASARECA/KIT. Tanzania Seed Sector Assessment: A Participatory National Seed Sector Assessment for the Development of an Integrated Seed Sector Development (ISSD) Programme in Tanzania. April 2014, Entebbe, Uganda Pp183.

[6] CTA. Seed Systems, Science and Policy in East and Central Africa 2014

[7] Etwire P. M., Atokple I. D. K., Buah S. S. J., Abdulai A. L., Karikari A. S. and Asungre P. Analysis of the seed system in Ghana. International Journal of Advance Agricultural Research 1, 2013, 713. 
[8] Ministry of Agriculture Food Security and Cooperatives. National Agriculture Policy, 2013.

[9] Adetumbi J. A., Saka J. O. and Fato B. F. Seed handling system and its implications on seed quality in South Western Nigeria. Journal of Agricultural Extension and Rural Development 2(6), 2010, 133-140.

[10] Lazaro, E.A. and Muywanga, D.M. Seed Production and Poverty Reduction: Case of Dodoma Rural District. Tanzania Journal Agriculture Science 8(2), 2008' 161-172.

[11] Sivaraj P., Philip H., Sriram N. and Pirabu J. V. A scale to measure attitude of agricultural professionals towards social media in Tamil Nadu. Journal of Pharmacognosy and Phytochemistry 6(6), 2017, 365-369.

[12] Ogunsumi, L. O. Attitude of farmers towards improved agricultural technologies in south-west Nigeria. African Journal of Biotechnology 10(50), 2011, 10108-10115.

[13] Chandra N. and Kumar S. A Scale to Measure Farmer's Attitude Towards Improved Agricultural Practices. Indian Research Journal of Extension Education 7 (2\&3), 2007, 30-31.

[14] Yirga C. and Alemu D. Adoption of Crop Technologies among Smallholder Farmers in Ethiopia: Implications for Research and Development. EIAR 50th Year Jubilee Anniversary Special Issue: 1-16, 2016.

[15] ESAFF. A Scoping Study Report on Seeds and Agriculture Research Process in Tanzania: The Case of Small scale farmers' participation in setting research agenda. Supported under the EU funded INSARD Project 2013.

[16] Mneney E., Mashindano O. and Nagarajan L. Tanzania Early Generation Seed Study. AGRA-SSTP FOR THE United State Agency for International Development 2016

[17] Letaa, E., Kabungo, C., Katungi, E., Ojara, M. and Ndunguru, A. Farm Level Adoption and Spatial Diffusion of Improved Common Bean Varieties in Southern Highlands of Tanzania. African Crop Science Journal 23(3), 2015, 261 - 277.

[18] De Luque J. J. R. and Creamer B. Major Constraints and trends for common bean production and commercialization; establishing priorities for future research. Agronomia Columbiana 32(3), 2014, 423-431.

[19] Katungi, E., Kikulwe, E. and Emongor, R. Analysis of farmers' valuation of common bean attributes and preference heterogeneity under environmental stresses of Kenya. African Journal of Agricultural Research 10(30), 2015, 2889-2901.

[20] Sichilima T., Mapemba L. and Tembo G. Drivers of Dry common beans trade in Lusaka, Zambia: A Traders Perspective. Sustainable Agriculture Research 5(2), 2016, 15-26.

\footnotetext{
*Corresponding author.

E-mail address: kidudujoshua@yahoo.com/dilmwase@yahoo.com/smsolla@ yahoo.com
} 